\title{
Öğretim Elemanlarının Bilinçli Farkındalıklarının ve Profesyonelliklerinin Örgütsel Çıktılara Etkisi*
}

\author{
Derya Eker Kaba ${ }^{\mathrm{a}}$ \\ Ayhan Aydın \\ a Öğr.Gör.Dr., Eskişehir Osmangazi Üniversitesi, ORCID: 0000-0001-5776-2848 \\ b Prof.Dr., Eskişehir Osmangazi Üniversitesi, ORCID: 0000-0002-0528-7245
}

\begin{tabular}{|c|c|}
\hline ÖZET & $\begin{array}{l}\text { MAKALE } \\
\text { BİLGİsí }\end{array}$ \\
\hline 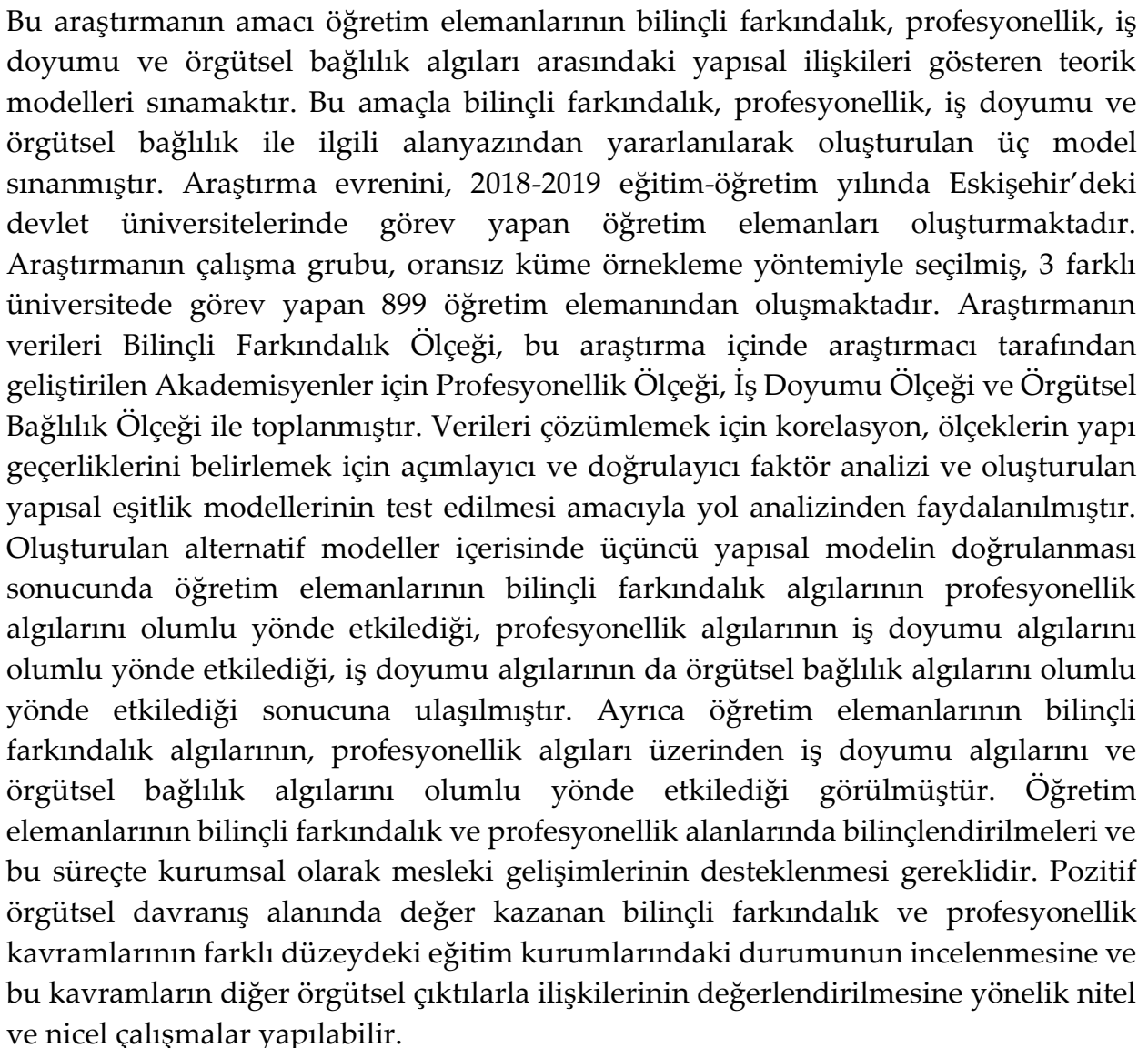 & $\begin{array}{l}\text { Anahtar } \\
\text { Kelimeler } \\
\text { Profesyonellik, } \\
\text { Bilinçli } \\
\text { Farkındalık, } \\
\text { İş Doyumu, } \\
\text { Örgütsel } \\
\text { Bağlllık }\end{array}$ \\
\hline
\end{tabular}

Atıf Bilgisi: Eker Kaba, D. ve Aydın, A. (2021). Öğretim elemanlarının bilinçli farkındalıklarının ve profesyonelliklerinin örgütsel çıktılara etkisi. Uluslararası Türk Ĕ̆̈itim Bilimleri Dergisi, 9 (16), 114-137.

Sorumlu yazar: Derya Eker Kaba, e-posta: drykyr@gmail.com

\footnotetext{
* Bu çalışma birinci yazarın ikinci yazar danışmanlığında hazırladığı “Öğretim Elemanlarının Profesyonelliklerinin ve Bilinçli Farkındalıklarının Örgütsel Çıktılara Etkisi” başlıklı tezden üretilmiştir. Bu çalışma için Eskişehir Osmangazi Üniversitesi'nden 27.05.2019 tarih ve 86930425-E.63806 sayı numarası ile Etik Kurul izni alınmıştır.
} 


\title{
The Effect of Mindful Awareness and Professionalism to the Organizational Outcomes*
}

\author{
Derya Eker Kaba ${ }^{\mathrm{a}}$ \\ Ayhan Aydin ${ }^{b}$ \\ a Dr., Eskişehir Osmangazi University, ORCID: 0000-0001-5776-2848 \\ b Prof.Dr., Eskişehir Osmangazi University, ORCID: 0000-0002-0528-7245
}

\begin{abstract}
This research aims to test the theoretical models formed to explain structural relations between the perceptions of academicians of mindful awareness, professionalism, job satisfaction, and organizational commitment. For this purpose, three structural models were formed based on the literature review and tested. The population of the research involves the academicians who were working in the public universities within Eskisehir province during the 2018-2019 academic year. The study group consists of 899 academicians who were selected by using a disproportionate cluster sampling method within three universities. The research data were collected through the Mindful Awareness Scale, Academicians' Professionalism Scale; the Job Satisfaction Scale and Organizational Commitment Scale. Correlation analysis was used to analyze the data, explanatory and confirmatory factor analysis was carried out to determine the structural validity of the scales, and Path analysis was used to test the structural equation models. The third model of the study was validated and it was observed that academicians' mindful awareness affects professionalism positively, professionalism affects job satisfaction positively and job satisfaction affects organizational commitment positively. It was observed that academicians' mindful awareness perceptions affect job satisfaction and organizational commitment perceptions via professionalism perceptions. It is necessary to raise the awareness of academic staff in the fields of conscious awareness and professionalism and to support their professional development institutionally in this process. Qualitative and Article Type

Research

Article

Background

Received:

31.12.2020

Accepted:

31.03.2021

Key Words

Mindful

Awareness,

Professionalism,

Job Satisfaction,

Organizational

Commitment quantitative studies can be conducted to examine the status of conscious awareness and professionalism in different educational institutions and to evaluate the relationship of these concepts with other organizational outcomes.
\end{abstract}

To cite this article: Eker Kaba, D. \& Aydın, A. (2021). The effect of mindful awareness and professionalism to the organizational outcomes. International Journal of Turkish Educational Sciences, 9 (16), 114-137.

Corresponding Author: Derya Eker Kaba, e-mail: drykyr@gmail.com

\footnotetext{
* This study was produced from the first author's dissertation titled "The effect of mindful awareness and professionalism to the organizational outcomes" supervised by the second author. The study was conducted by the approval of Ethics Committee in Eskişehir Osmangazi University dated 27.05.2019 and numbered 86930425-E.63806
} 


\section{Giriş}

Üniversite, evrensel ölçü ve standartlara sahip yükseköğretim sistemidir. Üniversitenin varlık nedenleri; kapsamlı ve kaliteli araştırmalar yapma, eğitim-öğretim hizmetleri verme ve evrensel anlamda nitelikli insan gücü yetiştirme olarak ifade edilebilir. Üniversiteler yeni bilimsel bilginin ortaya konması, onaylanması ve yayılmasında önemli bir rol oynamaktadır (Aydın, 2015; Başkan, 2001; Havas, 2008; Rasmussena, Moenb ve Gulbrandsenc, 2006). Üniversitelerde görev yapan öğretim elemanlarının özelliklerinin bilinmesi ve öğretim elemanlarına yapılan yatırımın arttırılması yükseköğretimde verimlilik ve etkililik sağlayabilmek için esastır. Örgütün verimliliği söz konusu olduğunda, psikoloji ve yönetim bilimleri örgüt çalışanlarının bireysel niteliklerinin güçlendirilmesini işaret etmektedir. Üniversite, insanlığın ihtiyaç duyacağı sevgi, barış, kardeşlik duygularını desteklemenin yanında patent, marka ve teknoloji üretimi yoluyla insanlığın gelişimine de olabilecek en üst seviyede katkı sağlamak durumundadır. Bu bağlamda üniversite misyonu inanç, değer, halk ve kültür ayrımı yapmaksızın eşit mesafede durmayı, insanlığa ait ortak değerleri yüceltmeyi, dünya halklarının barış içinde karşılıklı güven, anlayış ve saygı çerçevesinde yaşamalarını sağlamayı gerektirir (Aydın, 2015). Üniversitelerde sürecin verimli ve etkin bir şekilde işleyebilmesi için öğretim elemanlarının bireysel ve örgütsel bağlamda bilgi, beceri, mesleki gelişim ve iyi oluş düzeylerinin de değerlendirilmesi önem kazanmaktadır. Öğretim elemanları meslekleri gereği eğitim verme, bilimsel araştırmalar yapma ve bilimsel bulguları toplum yararına en etkili şekilde kullanma sorumluluklarını taşırlar. Böyle yüksek sorumlulukları taşıyan bir meslek grubundaki öğretim elemanlarının bilinçli farkındalıklarının ve profesyonellik düzeylerinin mesleki süreçleri üzerinde önemli bir etkisi olacağı düşünülmektedir. Bu noktada, öğretim elemanlarının bilinçli farkındalık ve profesyonellik düzeylerini ve bu kavramların örgütsel çıtılara etkisini inceleyen çalışmalara gereksinim duyulmaktadır.

Bilinçli farkındalık becerisi dikkatini sadece yaşanan ana vererek amaçlı bir şekilde yoğunlaşmayı ve bu eylemi tüm yargılardan uzak bir şekilde gerçekleştirmeyi gerektirir. Bu uygulamayla hedeflenen tepkisel olmayan, yargıdan arınmış ve odaklanmış bir dikkat ile şimdiki ana dair farkındalığı arttırabilmektir. Bilinçli farkındalık, yeni yaşam deneyimleri için gönüllü olmak ve hem kendini hem de başkalarını olduğu gibi kabul etmede önemli bir faktör olarak görülmektedir (Baer, Smith ve Allen, 2004; Brown ve Ryan, 2003). Eğitim kurumlarında kuralların, politikaların ve işleyişin sorgulamadan ve rutin bir şekilde izlenmesi sonucunda bireysel ve örgütsel eylemlerde bir bilinçsizlik durumu görülebilir. Bu açıdan bakıldığında kurallar, politika ve işleyişler eğitim kurumlarındaki verimlilik hedefini engelleyebilmektedir. Eğitim kurumlarında farkındalığın hedefi, sorunlar baş edilemez bir hal almadan önce küçük hataların tespit edilmesi ve var olan sorunları ayrıntılarıla analiz ederek ortadan kaldırabilmektir (Scarbrough, 2005).

Profesyonellik, bilinçli farkındalık kavramıla ilişkileri ve örgütsel çıktılara etkisi açısından dikkate alınması gereken kavramlardan biridir. Profesyonellik görevin uzmanlık ve yeterlilik doğrultusunda, belirli kalite ve standartlar çerçevesinde yapılması ve bu uzmanlığın sorun çözme aşamalarında da kullanılması anlamına gelmektedir (Svensson, 2003). Profesyonel birey belirli bir uzmanlık alanında yetkin ve gerekli becerilere sahip kişidir. Akademik profesyonellik kavramı tüm yönleriyle tanımlanması gereken ve hem yükseköğretim 
kurumları hem de paydaşları adına büyük bir önem taşımaktadır (Marginson, 2000; Nixon, 2004; Nixon, Rowland ve Walker, 2010). Örgüt yönetimi ortaya çıkan örgüt iklimi ile profesyonellerin özelliklerini etkilerken; örgütsel yapı profesyonelleşme sürecini, profesyoneller örgütsel yapıyı; profesyonel özelliklerin desteklenmesi ise örgütün genel performansinı etkilemektedir (Hall, 1967).

Bu araştırmada örgütsel çıtıların iş doyumu ve örgütsel bağlılık olarak belirlenmesinin sebebi bu iki kavram arasındaki ilişkinin farklı örgütler, farklı sosyoekonomik yapılar ve farklı kültürlerde pek çok ayrı çalışmayla ortaya konmuş olması ve akademisyenlerin profesyonellikleri ve bilinçli farkındalıklarının örgütsel çıktılara etkisini en güvenilir şekilde gösterebileceği düşüncesidir. Profesyonellik düzeyi yüksek bireylerde iş doyumunun da yüksek olduğu gözlemlenmektedir (Agho, 1993; Cheng, 1996; Pollard, 1995). Örgütsel düzeyde yapılan çalışmalarda ön plana çıkan araştırma konularından biri olan iş doyumu, bireyin sahip olduğu özelliklerin yapılan işin özellikleriyle uyum içerisinde olmasıdır. Birey, kendi standartları ile çalışırken bu standartların ne kadar karşılandığını değerlendirdiğinde ortaya çıkan durumsal farklılıklar iş doyumu algısı üzerinde belirleyici olmaktadır (McCormick ve Ilgen, 1980). Örgüt psikolojisi alanında iş doyumu kavramı genellikle bireylerin güdülenme seviyeleriyle ilgili olarak açıklanmaktadır. İş doyumu kişinin işini ve iş tecrübesini değerlendirmeden geçirdikten sonra hissettiği hoşuna giden, olumlu duygusal haldir (Davis, 1982; Locke 1970). İş doyumu ile olumlu ilişkileri alanyazın çalışmalarında da görülen örgütsel bağlılık kavramı, değişim adına önemli bir güç kaynağı ve örgütsel başarının elde edilebilmesi için vazgeçilemez bir unsurdur. Örgütsel bağlllık bir süreç içinde örgütün ve bireyin amaçlarını birbiriyle uyumlu hale getirerek bütünleştirir (Hall, Schneider ve Nygren, 1970). Çalışanlar, birbirinden bağımsız faydaları istikrarlı bir davranış planıyla ilişkilendirdiğinde örgütsel bağlılık ortaya çıkmaktadır (Becker, 1960). Örgüte bağl1lık duyan çalışanlar, örgütün hedef ve değerlerine gönülden inanmakta ve örgütün onlardan beklediği çabayı istekli bir şekilde yerine getirmektedirler. Ayrıca bu çalışanlar kendilerinden beklenen en az çabanın çok daha üzerinde bir çaba sarf ederek örgütte kalmak istemekte, eylemin kendisiyle ve elde edilen başarıyla bağlantılı bir içsel güdülenme davranışı içine girmektedirler (Firestone ve Pennell, 1993).

Yapılan çalışmalar incelendiğinde bu araştırma kapsamındaki bilinçli farkındalık, profesyonellik, iş doyumu ve örgütsel bağlılık değişkenlerine dair belirli bazı sonuçlara varılmıştır. Bilinçli farkındalık profesyonelliği olumlu yönde etkilemektedir. Bilinçli farkındalık düzeyleri yüksek bireylerin benzer şekilde yüksek profesyonellik düzeylerine sahip oldukları görülmüştür (Ludmerer, 1999; Wang, 2007; Lovas, Lovas ve Lovas, 2008). Bilinçli farkındalığın yüksek oluşu bireylerin profesyonellik düzeylerini, karar verme süreçlerini, liderlik süreçlerini ve etik algılarını olumlu yönde etkilemektedir (Huang, 2015). Profesyonellik düzeyinin yüksekliği iş doyumunu artırıcı bir etkiye sahiptir. Yapılan çalışmalarda iş doyumu ve mesleki profesyonellik arasında olumlu yönde ilişkiler ortaya konmuştur (Agho, 1993; Altınkurt ve Yilmaz, 2014; Lok, 1999; Pearson ve Moomaw, 2005; Pollard, 1995). Yüksek profesyonellik düzeyine sahip okullarda iş doyumu düşük profesyonellik düzeyine sahip okullara kıyasla daha yüksektir (Cheng, 1996). Alanyazın incelemesinde iş doyumu ve örgütsel bağlılık arasında olumlu yönde yüksek derecede ilişkiler görülmüştür. İş doyumu örgütsel bağl1lığın önemli bir yordayıcısıdır (Curry, 1986; Moorman, Niehoff ve Organ 1993; Nguni, Sleegers ve Denessen 2006; Tett ve Meyer 1993). Bu bağlamda, 
üniversitelerde görevli öğretim elemanlarının bilinçli farkındalıklarının ve profesyonellik düzeylerinin örgütsel çıktılara etkisi yapısal eşitlik modellemesi kullanılarak incelenmiştir. Araştırma kapsamında yapısal eşitlik modellemesi kullanarak bu değişkenlerin aynı anda test edilmesi sağlanmıştır.

\section{Araştırmanın Hipotezleri}

Araştırma hipotezleri şu şekilde belirlenmiştir;

H1. Bilinçli farkındalığın profesyonellik üzerinde etkisi vardır,

H2. Bilinçli farkındalığın iş doyumu üzerinde etkisi vardır,

H3. Bilinçli farkındalığın örgütsel bağlılık üzerinde etkisi vardır,

H4. Profesyonelliğin iş doyumu üzerinde etkisi vardır,

H5. Profesyonelliğin örgütsel bağlılık üzerinde etkisi vardır,

H6. İş doyumunun örgütsel bağlılık üzerinde etkisi vardır.

\section{Yöntem}

Bu çalışma için Eskişehir Osmangazi Üniversitesi'nden 27.05.2019 tarih ve 86930425-E.63806 sayı numarası ile Etik Kurul izni alınmıştır.

\section{Araştırmanın Modeli}

$\mathrm{Bu}$ araştırmanın amacı yükseköğretim kurumlarında çalışan öğretim elemanlarının bilinçli farkındalıkları, profesyonellikleri, iş doyumları ve örgütsel bağlılıkları arasında bir ilişki olduğu ve bu ilişki içerisinde profesyonellik ve bilinçli farkındalığın yordayıcı rol üstlendiği şeklinde oluşturulan teorik bir modeli test etmektir. Araştırma ilişkisel desende tasarlanarak, yapısal ilişkilerin incelenmesi amaçlanmıştır. İlişkisel desende tasarlanan araştırmalarda amaç değişkenler arasındaki bağlantıların ve ilişkilerin incelenebilmesidir (Büyüköztürk, Çakmak, Akgün, Karadeniz ve Demirel, 2017; Fraenkel ve Wallen, 2006; Neuman ve Robson, 2007). Bu araştırmada alternatif modeller stratejisinden yola çıkılmış; öğretim elemanlarının profesyonellikleri, bilinçli farkındalıkları, iş doyumları ve örgütsel bağlılıkları değişkenleri arasında neden-sonuç ilişkileri olacağı düşüncesiyle farklı araştırma modelleri oluşturulmuştur. Araştırmanın birinci modeli, öğretim elemanlarının profesyonelliklerinin ve bilinçli farkındalıklarının öğretim elemanlarının iş doyumlarını; iş doyumunun da öğretim elemanlarının örgütsel bağlılıklarını etkilediğini varsaymaktadır. Araştırmanın ikinci modeli öğretim elemanlarının bilinçli farkındalıklarının profesyonelliği; profesyonelliğin ise iş doyumunu ve örgütsel bağlılı̆̆1 etkilediğini ifade etmektedir. Araştırmanın üçüncü modeli öğretim elemanlarının bilinçli farkındalıklarının bir nedensellik doğrultusunda profesyonelliği; profesyonelliğin ise iş doyumunu ve gene bir nedensellik doğrultusunda iş doyumunun da örgütsel bağlılığı etkilediğini ifade eden lineer bir modeldir.

\section{Evren ve Örneklem}

Araştırmanın evrenini, 2018-2019 eğitim-öğretim yılında, Eskişehir'deki Anadolu 
Üniversitesi, Eskişehir Teknik Üniversitesi ve Eskişehir Osmangazi Üniversitesi'nde görev yapan 3790 öğretim elemanı; araştırmanın örneklemini ise oransız küme örnekleme yöntemiyle seçilen 899 öğretim elemanı oluşturmaktadır. Oransız küme örnekleme yönteminin faydaları araştırmanın büyük bir fiziki alana yayılmasını engelleyerek maliyeti düşürmesi ve fizik alanın küçülmesiyle beraber denetim imkânlarını arttırmasıdır (Karasar, 2005). Araştırma örnekleminin evreni temsil gücünü hesaplamada evreni oluşturan 3790 öğretim elemanı üzerinden, \%95 güven aralığında hata payı olarak .05 kabul edilerek araştırmaya ait yapısal modellerin test edilebilmesi için örneklem sayısı en az 349 olarak hesaplanmıştır (Hamburg, 1995). Araştırmanın örneklemini, Anadolu Üniversitesi, Eskişehir Teknik Üniversitesi ve Eskişehir Osmangazi Üniversitesi'nde 2018-2019 eğitim öğretim yılında görev yapmakta olan ve gönüllülük esasına göre çalışmaya katılmayı kabul eden öğretim elemanları oluşturmaktadır. Araştırma katılımcılarının demografik verileri (n: 899) Tablo 1'de görülebilir.

Tablo 1. Araştırmanın Örneklemine İlişkin Demografik Veriler

\begin{tabular}{lcr}
\hline & n & $\%$ \\
\hline Cinsiyet & 483 & 54 \\
Kadın & 416 & 46 \\
Erkek & & \\
Eğitim Durumu & 35 & 38 \\
Lisans & 345 & 58 \\
Yüksek Lisans & 519 & \\
Doktora & & 36 \\
Çalıştığı Üniversite & 326 & 35 \\
Eskişehir Osmangazi Üniversitesi & 314 & 29 \\
Anadolu Üniversitesi & 259 & 100 \\
Eskişehir Teknik Üniversitesi & 899 & \\
Toplam
\end{tabular}

Tablo 1'de görüldüğü üzere araştırma örnekleminde yer alan öğretim elemanlarının 483'ü (\%54) kadın, 416'sı (\%46) erkektir. Örneklemde yer alan öğretim elemanlarının 35'i (\%4) lisans, 345'i (\%38) yüksek lisans, 519'u (\%58) da doktora diploması sahibidir. Araştırma örneklemindeki öğretim elemanlarının 326'sı (\%36) Eskişehir Osmangazi Üniversitesi'nde, 314'ü (\%35) Anadolu Üniversitesi'nde, 259'u (\%29) Eskişehir Teknik Üniversitesi'nde görevlidir.

\section{Veri Toplama Araçları}

$\mathrm{Bu}$ araştırmadaki veriler beş farklı bölümden oluşan bir araştırma aracı kullanılarak elde edilmiştir. Araştırma aracının ilk bölümü demografik bilgilerden (cinsiyet, eğitim durumu, 
çalışttğ üniversite); ikinci bölümü "Öğretim Elemanları için Profesyonellik Ölçeği”, üçüncü bölümü "Bilinçli Farkındalık Ölçeği”, dördüncü bölümü "Minnesota İş Tatmini Ölçeği”, beşinci bölümü “Örgütsel Bağlılık Ölçeği”nden oluşmaktadır.

\section{Öğretim Elemanları için Profesyonellik Ölçeği}

Öğretim elemanlarının akademik profesyonelliklerini ölçmek amacıyla araştırmacı tarafından bu araştırma kapsamında Öğretim Elemanları için Profesyonellik Ölçeği geliştirilmiştir. Ölçek toplam 19 madde ve mesleki gelişim boyutu, öz yeterlilik boyutu, iş birliği boyutu, kurumsal boyut ve toplumsal boyut olmak üzere 5 faktörden oluşmaktadır.

Araştırma esnasında uygulanan bütün ölçme araçlarının geçerlik analizleri için yapılan doğrulayıcı faktör analizlerine dahil edilen uyum indeksleri: uyum iyiliği indeksi (GFI), düzeltilmiş uyum iyiliği indeksi (AGFI), karşılaştırmalı uyum indeksi (CFI), normlaştırılmamış uyum indeksi (NFI), ortalama hataların karekök ortalaması (RMSEA), serbestlik derecesi (df), ki-kare istatistiği $(\chi 2)$ ve $\chi 2 / \mathrm{df}$ oranıdır (Bollen, 1989; Browne ve Cudeck, 1993; Byrne, 2010; Cole, 1987; Hu ve Bentler, 1999; Kline, 2005; Schumacker ve Lomax, 1996; Tanaka ve Huba, 1985).Uyum indekslerinin kabul edilebilir değerleri Tablo 2'de verilmiştir.

Tablo 2. Doğrulayıcı Faktör Analizi Uyum İndekslerinin Kabul Edilebilir Değerleri

\begin{tabular}{lll}
\hline Uyum İndeksi & İyi Uyum & Kabul Edilebilir Uyum \\
\hline GFI & $\geq 0,90$ & $0,89-0,85$ \\
AGFI & $\geq 0,90$ & $0,89-0,85$ \\
CFI & $\geq 0,90$ & $0,89-0,85$ \\
NFI & $\geq 0,90$ & $0,89-0,85$ \\
RMSEA & $\leq 0,05$ & $0,06-0,10$ \\
$\chi^{2} /$ df & $\leq 3$ & $\leq 4-5$ \\
\hline
\end{tabular}

Ölçeğin yapı geçerliğini değerlendirebilmek için kullanılan doğrulayıcı faktör analizi (DFA) sonucuna göre ölçeğin uyum indeksleri $\left(\chi^{2}=667.28 ; \mathrm{df}=137 ; \chi 2 / \mathrm{df}=4.87 ; \mathrm{GFI}=0.92 ; \mathrm{CFI}=0.93\right.$; AGFI=0.89; NFI=0.91; RMSEA=0.07) şeklinde elde edilmiştir. Bu araştırmada yapılan DFA sonrasında ölçeğin güvenirliği iç tutarlılık yöntemiyle belirlenmiştir. Ölçeğin tamamı için Cronbach Alfa katsayısı 0.79'dur. Ölçeğin tamamı ve alt boyutları için elde edilen Cronbach Alfa iç tutarlılık katsayıları incelendiğinde mesleki gelişim boyutu için 0.57, öz yeterlilik alt boyutu için 0.71 , iş birliği alt boyutu için 0.69 , kurumsal etkileşim alt boyutu için 0.65 ve toplumsal fayda alt boyutu için 0.90 olarak hesaplanmıştır. Özdamar (1999) Cronbach Alfa güvenirlik katsayısına dair ölçüt değerleri şu şekilde belirtilmiştir;

$0.00<\alpha<0.40$ ise ölçek güvenilir değildir,

$0.00<\alpha<0.60$ ise ölçek güvenilirliği düşüktür,

$0.61<\alpha<0.80$ ise ölçek güvenilirliği orta düzeydedir, 
Öğretim Elemanlarının Bilinçli Farkındalıklarının ve Profesyonelliklerinin Örgütsel Çıktılara Etkisi

$0.81<\alpha<1.00$ ise ölçek güvenilirliği yüksek düzeydedir.

Bu ölçüt değerler dikkate alındığında öğretim elemanları için profesyonellik ölçeğinin ®=0.79 ile orta düzeyde bir güvenirlik katsayısına sahip olduğu görülmektedir.

\section{Bilinçli Farkındalık Ölçeği}

Brown ve Ryan (2003) tarafından geliştirilmiş olan Bilinçli Farkındalık Ölçeği (BİFÖ), günlük yaşamdaki anlık tecrübelerin farkında ve bunlara karşı dikkatli olma yönündeki genel eğilimi ölçen 15 maddeden oluşan bir ölçektir. BİFÖ tek faktörlü bir yapıya sahiptir ve tek bir toplam puan verir. Bu araştırmada, DFA için hazırlanan modelde ölçeğin orijinal formunda olduğu gibi tek faktörlü bir yapısal model kurulmuş ve yapılan doğrulayıcı faktör analizi sonucunda uyum indeksleri $\quad\left(\chi^{2}=519.95 ; \quad \mathrm{df}=115 ; \quad \chi 2 / \mathrm{df}=4.52 ; \quad \mathrm{GFI}=0.92 ; \quad \mathrm{CFI}=0.94 ; \quad \mathrm{AGFI}=0.89\right.$ ve RMSEA=0.07) olarak hesaplanmıştır. DFA sonrasında ölçeğin güvenirliği iç tutarlılık yöntemiyle belirlenmiştir. Ölçek için Cronbach Alfa iç tutarlılık katsayısı 0.84'tür.

\section{Minnesota İş Tatmini Ölçeği}

İş tatmini ölçümünü yapabilmek için Weiss, Dawis ve England (1967) tarafından geliştirilmiş olan Minnesota İş Tatmini Ölçeği araştırmaya dahil edilmiştir. Ölçeğin İngilizce' den Türkçe' ye çevirisi Hacettepe Üniversitesi'nden 1985 yılında Deniz ve Güliz Gökçora tarafından yapılmıştır (Baycan,1985). Ölçek 20 maddeden oluşmaktadır. Ölçekte içsel tatmin, dışsal tatmin ve genel tatmin olmak üzere üç boyut vardır. 1'den 20'ye kadar tüm sorular ise genel tatmini ifade etmektedir. (İçsel tatmin+dışsal tatmin+2 soru). Bu araştırma kapsamında, ölçeğin yapı geçerliğini inceleyebilmek adına doğrulayıcı faktör analizi yapılmıştır. Bu araştırmada, ölçeğin doğrulayıcı faktör analizinde genel tatmine yönelik tek faktörlü bir yapısal model kurulmuş ve DFA analizi sonucunda uyum indeksleri $\left(\chi^{2}=584.85 ; \mathrm{df}=120\right.$; $\chi 2 / \mathrm{df}=4.87 ; \mathrm{GFI}=0.92 ; \mathrm{CFI}=0.94 ; \mathrm{AGFI}=0.90$ ve $\mathrm{RMSEA}=0.07$ ) olarak belirlenmiştir. Minnesota İş Tatmini Ölçeği için Cronbach Alfa katsayısı 0.89'dur.

\section{Örgütsel Bağlılık Ölçeği}

Örgütsel Bağlılık Ölçeği Meyer ve Allen tarafından 1991 yılında geliştirilmiştir. Ölçek 24 madde ve 3 faktörden oluşmaktadır ve 1993 yılında Meyer, Allen ve Smith tarafından revize edilmiştir. Ölçeğin son hali 18 madde ve 3 faktörden oluşmaktadır (Meyer, Allen ve Smith, 1993). Ölçeğin güvenilirliği alanda yapılan ilgili araştırmalarda test edilmiştir. Örgütsel Bağlılık Ölçeği için geçerlilik ve güvenilirlik analizi Wasti (2000) tarafından yapılarak Türk kültürüne uygunluğu saptanmıştır. Bu araştırmada, ölçeğin yapı geçerliğini inceleyebilmek adına doğrulayıcı faktör analizi (DFA) yapılmıştır. Bu araştırmada, ölçeğin doğrulayıcı faktör analizinde ölçeğin orijinal formunda olduğu gibi üç faktörlü bir yapısal model oluşturulmuş ve DFA analizi sonucunda uyum indeksleri $\left(\chi^{2}=439.92 ; \mathrm{df}=109 ; \chi^{2} / \mathrm{df}=4.03 ; \mathrm{GFI}=0.92 ; \mathrm{CFI}=0.96\right.$; AGFI=0.88; NFI=0.95 ve RMSEA=0.07) olarak bulunmuştur. DFA sonrasında ölçeğin güvenirliği iç tutarlılık yöntemiyle belirlenmiştir. Ölçeğin tamamı için Cronbach Alfa katsayısı 0.85 'tir. Ölçeğin alt boyutları için elde edilen Cronbach Alfa iç tutarlılık katsayıları incelendiğinde duygusal bağlılık boyutu için 0,57, devam bağlılığı alt boyutu için 0,71 ve normatif bağl1lık alt boyutu için 0,69 olarak hesaplanmıştır. 


\section{Verilerin Analizi}

Yapısal eşitlik modeli uygulamasına geçilmeden önce verilerin uygunluğu açısından kayıp veri analizi yapılmış, uç değerler belirlenmiş, normal dağılım, doğrusallık, eşvaryanslılık ve çoklu doğrusal bağlantı değerlendirmeleri gerçekleştirilmiştir (Tabachnick ve Fidell, 2013). Ölçeklerin üniversitelerde görev yapan öğretim elemanlarına uygulanması sonucunda elde edilen ölçeklerden geçerli olmadığı düşünülenler çalışmadan çıkarılmıştır. Geriye kalan ölçeklerdeki bütün maddeler üzerinde kayıp veri analizi yapılmıştır. Görülen tek kayıp veriye ise orta değer ataması yapılmıştır. Uygulamadan elde edilen veri setindeki her madde için zpuanı incelemesi yapılarak belirlenen uç değerler $(n=68)$ veri setinden çıkarılmıştır.

Verilerin normal dağılıma uygun olup olmadığını kontrol edebilmek için basıklık ve çarpıklık değerleri dikkate alınmıştır. Normal dağılım için basıklık değerinin 3'ten küçük, çarpıklık değerinin ise 10 değerinin altında olduğu durumlarda verilerin normal dağıldığı ifade edilmektedir (Kline, 2005). Bu araştırmada kullanılan değişkenlere ait toplanan verilerin normal dağılıma uygunluğunu incelemek amacıyla uygulanan istatistiksel işlem sonucunda verilerin normal dağıldığı gözlemlenmiştir. Söz konusu çarpıklık ve basıklık değerleri Tablo 3’Te gösterilmektedir.

Tablo 3. Değişkenlere İlişkin Çarpıklık-Basıklık Değerleri

\begin{tabular}{lll}
\hline Değişken & Çarpıklık & Basıklık \\
\hline 1-Bilinçli Farkındalık & -0.54 & 0.15 \\
2-Profesyonellik & -0.22 & 0.06 \\
3-İş Doyumu & -0.4 & 1.00 \\
4-Örgütsel Bağlılık & -0.38 & -0.39 \\
\hline
\end{tabular}

Değişkenler arasında doğrusal ya da doğrusala yakın bir ilişki olduğunda doğrusallık görülmektedir. Doğrusal ilişkiler saçılım grafiğindeki ilişkilere bakılarak incelenmektedir (Tabachnick, 2013). Bu araştırma kapsamındaki değişkenler arasındaki ilişkiler için oluşturulan saçlım grafikleri incelendiğinde, doğrusal olmayan ilişkiler görülmemiştir. Bu araştırmada doğrusallık varsayımı karşılanmakta ve varyanslar homojen dağılmaktadır. Değişkenler arasındaki ilişkinin aşırı yüksek olması durumunda çoklu bağlantıdan söz edilmektedir. Değişkenler arasında yüksek ilişkiler tespit edildiğinde, bu durum söz konusu değişkenlerin aynı yapıyı ölçtüklerini göstermektedir. İki ayrı değişken arasındaki korelasyon katsayısı 0.90'ın üzerine çıkarsa çoklu bağlantı varsayımı sağlanamamaktadır (Kline, 2005). Bu araştırmadaki değişkenlerin korelasyon katsayıları $0.85^{\prime}$ ten düşük olduğu için çoklu bağlantı varsayımı sağlanmaktadır (bkz. Tablo 3).

\section{Bulgular}

Araştırma verilerinin yapılacak analizlere uygunluğunun tespit edilmesi ve yapısal eşitlik modellemesi için gereken varsayımların sağlanması aşamalarından sonra bu bölümde öğretim elemanlarının bilinçli farkındalık, profesyonellik, iş doyumu ve örgütsel bağlılık algılarını 
ortaya koyabilmek için çalışma değişkenlerine dair ortalama değer ve standart sapma gibi betimsel istatistikler sunulmuştur. Araştırmaya katılan öğretim elemanlarının Bilinçli Farkındalık Ölçeği, Öğretim Elemanları için Profesyonellik Ölçeği, İş Doyumu Ölçeği ve Örgütsel Bağllılı Ölçeği'nin alt boyut puanlarına ilişkin ortalamalar ve standart sapma değerleri Tablo 4'te gösterilmektedir. Tablo 3'ten anlaşılacağı üzere, öğretim elemanlarının bilinçli farkındalık algıları 5'li skala üzerinden değerlendirildiğinde 3.83'tür. Öğretim elemanlarının profesyonellik algıları ise 5'li derecelendirme üzerinden mesleki gelişim alt boyutunda 4.38; öz yeterlilik alt boyutunda 3.74; iş birliğine açıklık alt boyutunda 4.21; akademik etkileşim alt boyutunda 4.12 ve toplumsal fayda alt boyutunda 4.15 olarak hesaplanmıştır. Öğretim elemanlarının iş doyumu algıları 5'li derecelendirme üzerinden 3.82 olarak değerlendirilmiştir. Öğretim elemanlarının örgütsel bağlılık algıları 5'li derecelendirme üzerinden değerlendirilmiş ve duygusal bağlılık alt boyutunda 4.38; devam bağlılığı alt boyutunda 3.45 ve normatif bağlılık alt boyutunda 3.19 olarak hesaplanmıştır.

Tablo 4. Öğretim Elemanlarının Bilinçli Farkındalık, Profesyonellik, İş Doyumu ve Örgütsel Bağlılık Algılarına İlişkin Betimleyici İstatistikler

\begin{tabular}{llccc}
\hline Değişken & Alt Boyutlar & $\mathrm{n}$ & $\mathrm{X}$ & $\mathrm{SS}$ \\
\hline Bilinçli Farkındalık & & 830 & 3.83 & 0.54 \\
Profesyonellik & 1. Mesleki gelişim & 830 & 4.38 & 0.40 \\
& 2. Öz yeterlilik & 830 & 3.74 & 0.66 \\
& 3. İş birliğine açıklık & 830 & 4.21 & 0.54 \\
& 4. Akademik etkileşim & 830 & 4.12 & 0.59 \\
& 5. Toplumsal Fayda & 830 & 4.15 & 0.73 \\
İş Doyumu & & 830 & 3.82 & 0.61 \\
Örgütsel Bağlılık & 1. Duygusal Bağlllık & 830 & 3.61 & 0.97 \\
& 2. Devam Bağlılı̆̆1 & 830 & 3.45 & 0.76 \\
& 3. Normatif Bağlılık & 830 & 3.19 & 0.85 \\
\hline
\end{tabular}

Araştırma modelindeki gizil ve gözlenen değişkenleri arasındaki Pearson korelasyon değerleri Tablo 5'te verilmiştir.

Tablo 5'te görüldüğü gibi, araştırma modelinin gizil değişkenleri olan bilinçli farkındalık, profesyonellik, iş doyumu ve örgütsel bağlılık değişkenleri arasında anlamlı ilişkiler vardır. Değişkenler arasındaki korelasyon değerleri 0.10 değerinden düşük ise düşük korelasyonu, 0.30 ise orta düzeyde korelasyonu ve 0.50 civarında ise yüksek korelasyonu göstermektedir (Field, 2009). Bu araştırmada profesyonellik değişkeni bilinçli farkındalık ve iş doyumu ile olumlu yönde orta düzeyde bir korelasyona sahipken diğer değişkenlerden örgütsel bağlılık ile yine olumlu yönde fakat nispeten düşük korelasyona sahiptir. Örgütsel bağlllık ile iş doyumu arasında olumlu yönde yüksek bir korelasyon olduğu söylenebilir. 
Tablo 5. Araştırma Modelindeki Gözlenen ve Gizil Değişkenlere İlişkin Korelasyonlar

\begin{tabular}{|c|c|c|c|c|c|c|c|c|c|c|c|c|c|c|}
\hline & 1 & 2 & 3 & 4 & 5 & 6 & 7 & 8 & 9 & 10 & 11 & 12 & 13 & 14 \\
\hline \multicolumn{15}{|l|}{ Gizil Değişkenler } \\
\hline $\begin{array}{l}\text { 1- Bilinçli } \\
\text { Farkındalık }\end{array}$ & 1 & $0,234^{* *}$ & $0,084^{*}$ & $0,115^{* *}$ & $10,000^{*}$ & $0,180^{* *}$ & $0,175^{* *}$ & $0,128^{* *}$ & $0,154^{* *}$ & $0,147^{* *}$ & $0,084^{*}$ & $0,156^{* *}$ & $-0,75^{*}$ & $0,164^{* *}$ \\
\hline 2- Profesyonellik & & 1 & $0,335^{* *}$ & $0,125^{* *}$ & $0,234^{* *}$ & $0,593^{* *}$ & $0,688^{* *}$ & $0,750^{* *}$ & $0,712^{* *}$ & $0,579^{* *}$ & $0,335^{* *}$ & $0,215^{* *}$ & $-0,10^{* *}$ & $0,142^{* *}$ \\
\hline 3- İş Doyumu & & & 1 & $0,448^{* *}$ & $0,084^{*}$ & $0,160^{* *}$ & $0,229^{* *}$ & $0,243^{* *}$ & $0,287^{* *}$ & $0,173^{* *}$ & $10,000^{*}$ & $0,448^{* *}$ & $0,111^{* *}$ & $0,412^{* *}$ \\
\hline 4- Örgütsel bağlılık & & & & 1 & $0,115^{* *}$ & 0,32 & $0,091^{* *}$ & $0,085^{*}$ & $0,152^{* *}$ & 0,019 & $0,448^{* *}$ & $0,839^{* *}$ & $0,644^{* *}$ & $0,856^{* *}$ \\
\hline \multicolumn{15}{|c|}{ Gözlenen Değişkenler } \\
\hline 5- BF & & & & & 1 & $0,180^{* *}$ & $0,175^{* *}$ & $0,128^{* *}$ & $0,154^{* *}$ & $0,147^{* *}$ & $0,084^{*}$ & $0,156^{* *}$ & $-0,75^{*}$ & $0,164^{* *}$ \\
\hline 6- P1 & & & & & & 1 & $0,240^{* *}$ & $0,346^{* *}$ & $0,331^{* *}$ & $0,303^{* *}$ & $0,160^{* *}$ & $0,072^{*}$ & $-0,035$ & 0,025 \\
\hline 7- P2 & & & & & & & 1 & $0,284^{* *}$ & $0,198^{* *}$ & $0,213^{* *}$ & $0,229^{* *}$ & $0,148^{* *}$ & $-0,15^{* *}$ & $0,184^{* *}$ \\
\hline 8- P3 & & & & & & & & 1 & $0,557^{* *}$ & $0,382^{* *}$ & $0,243^{* *}$ & $0,182^{* *}$ & $-0,044$ & 0,034 \\
\hline 9- P4 & & & & & & & & & 1 & $0,333^{* *}$ & $0,287^{* *}$ & $0,222^{* *}$ & $-0,032$ & $0,136^{* *}$ \\
\hline 10- P5 & & & & & & & & & & 1 & $0,173^{* *}$ & 0,042 & $-0,004$ & 0,000 \\
\hline 11- İD & & & & & & & & & & & 1 & $0,448^{* *}$ & $0,111^{* *}$ & $0,412^{* *}$ \\
\hline 12- ÖB1 & & & & & & & & & & & & 1 & $0,254^{* *}$ & $0,633^{* *}$ \\
\hline 13- ÖB2 & & & & & & & & & & & & & 1 & $0,356^{* *}$ \\
\hline 14- ÖB3 & & & & & & & & & & & & & & 1 \\
\hline
\end{tabular}


Araştırmanın gözlenen değişkenleri arasındaki ilişkilere bakıldığında, bilinçli farkındalık (BF) ve diğer değişkenler arasında anlamlı ilişkiler görülmüştür. Profesyonelliğin alt boyutlarından mesleki gelişim alt boyutu (P1) ile örgütsel bağlılık alt boyutlarından devam bağlılığı ve normatif bağlılık alt boyutları (B2 ve B3) arasında anlamlı ilişkiler olmadığı görülmüştür. Profesyonelliğin alt boyutlarından öz yeterlilik alt boyutu (P2) ile diğer tüm değişkenler arasında anlamlı ilişkiler görülmüştür. Profesyonelliğin alt boyutlarından iş birliği alt boyutu (P3) ile örgütsel bağl1lık alt boyutlarından devam bağl1lı̆ğ ve normatif bağlılık alt boyutları (B2 ve B3) arasında ve gene profesyonelliğin alt boyutlarından kurumsal etkileşim alt boyutu (P4) ile devam bağ lılığı (B2) arasında anlamlı ilişkiler olmadığı sonucuna ulaşılmıştır. Bunlara ek olarak profesyonelliğin alt boyutlarından toplumsal fayda alt boyutu (P5) ile örgütsel bağlılık ve alt boyutları duygusal bağlılık, devam bağlılığı ve normatif bağllık alt boyutları (B1, B2 ve B3) arasında anlamlı ilişkiler olmadığı sonucuna ulaşılmıştır. Son olarak, iş doyumu ölçeğinin madde ortalamaları (ID) ile diğer değişkenlerin alt boyutları arasında da anlamlı ilişkiler görülmüştür.

\section{Model I'e İlişkin Bulgular}

Oluşturulan ilk yapısal modeldeki gizil değişkenler arasındaki nedensel ilişkileri gösterebilmek için yapılan yol analizi sonucunda uyum indeksleri $\chi^{2}=213.90 ; \mathrm{df}=33 ; \chi^{2} / \mathrm{df}=6.48$; $\mathrm{GFI}=0.95 ; \mathrm{CFI}=0.91 ; \mathrm{AGFI}=0.92$ ve $\mathrm{RMSEA}=0.081$ olarak elde edilmiştir. Araştırmanın birinci modelinin $\chi^{2} / \mathrm{df}$ uyum iyiliği değerleri dikkate alındığında ölçme modelinin kabul edilebilir bir model olduğu söylenemez. Yapısal eşitlik modelinde elde edilen $\mathrm{t}$ değerleri her bir gözlenen değişkenin gizil değişken tarafından ne derece anlamlı yordandığını göstermektedir; 0.05 anlamlılık düzeyinde eşik t değeri 1.96, 0.01 anlamlılık düzeyinde ise eşik değeri $2.576{ }^{\prime}$ dır (Şimşek, 2007). Birinci yapısal eşitlik modelindeki ilişkilerin anlamlı olup olmadıklarını incelemek için yapılan t-testi analizi Şekil 1'de görülebilir.

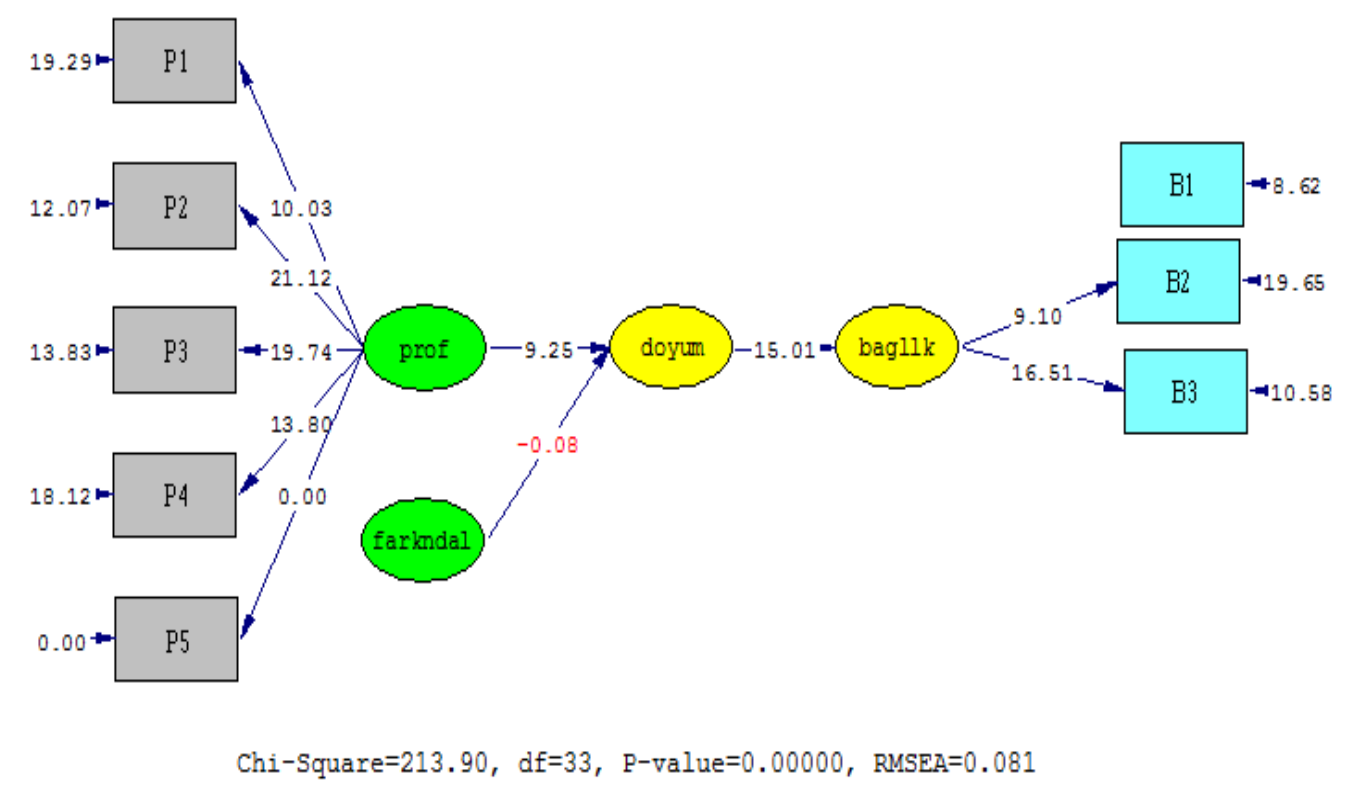

Şekil 1. Birinci Yapısal Eşitlik Modeli t Değerleri 
Yapılan t-testi analizine göre bilinçli farkındalık ve iş doyumu arasındaki ilişkiler anlamlı değildir ( $p>0.01$ ). Bu sebeple birinci modelde oluşturulan yapıdan vazgeçilerek oluşturulan ikinci model test edilmiştir.

\section{Model II'ye İlişkin Bulgular}

İkinci yapısal modeldeki gizil değişkenler arasındaki nedensel ilişkileri gösterebilmek için gerçekleştirilen yol analizi sonucunda uyum indeksleri $\chi^{2}=386.80 ; \mathrm{df}=34 ; \chi^{2} / \mathrm{df}=11.37 ; \mathrm{GFI}=0.91$; $\mathrm{CFI}=0.83$; $\mathrm{AGFI}=0.86$ ve $\mathrm{RMSEA}=0.11$ olarak bulunmuştur. Araştırmanın ikinci yapısal eşitlik modelinin $\chi^{2} / \mathrm{df}$ uyum iyiliği ve RMSEA değerleri dikkate alındığında ölçme modelinin kabul edilebilir bir model olmadığ1 görülmektedir (Bollen, 1989; Browne ve Cudeck, 1993; Byrne, 2010; Cole, 1987; Hu ve Bentler, 1999; Kline, 2005; Schumacker ve Lomax, 1996; Tanaka ve Huba, 1985). Bu sebeple ikinci modeldeki yapıdan vazgeçilmiş ve araştırmanın üçüncü modeli test edilmiştir (Bkz. Şekil 2).

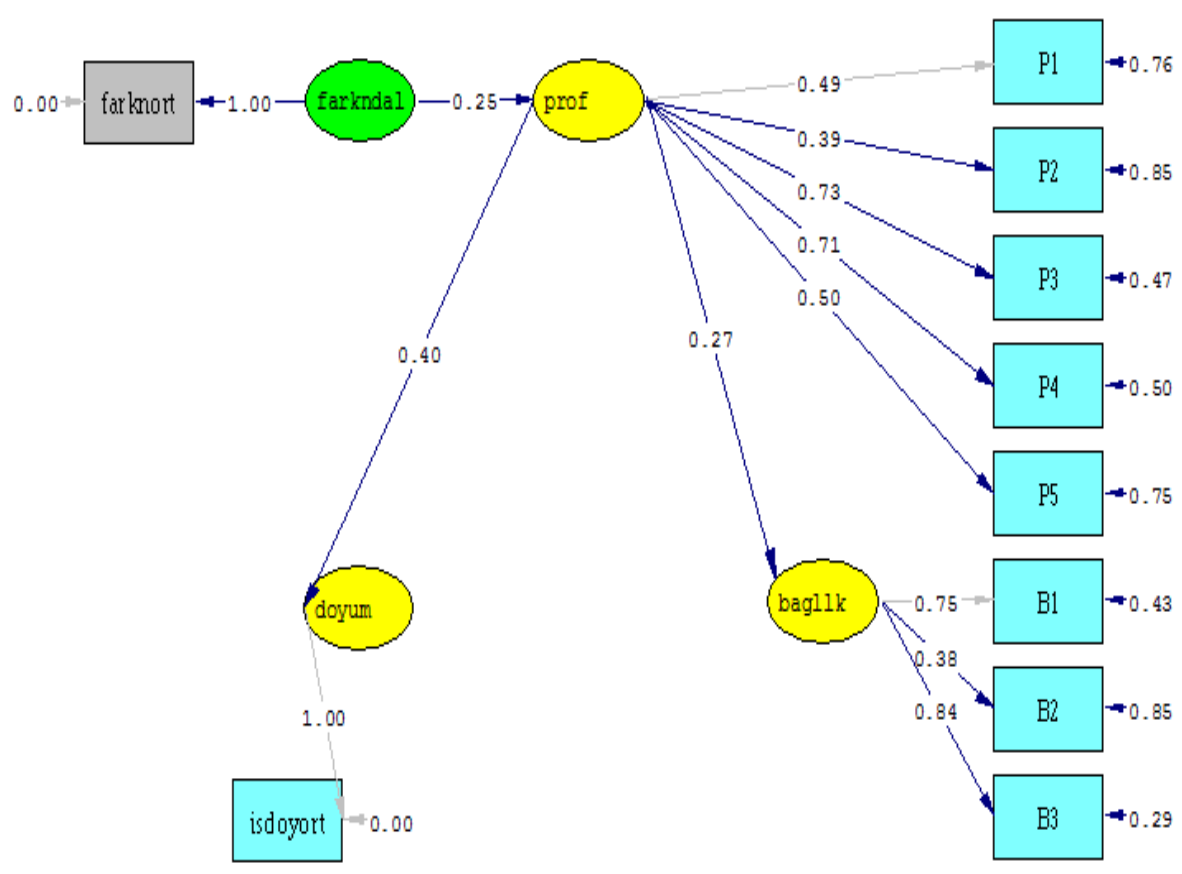

Chi-Square $=386.80, d f=34, \mathrm{P}-\mathrm{value}=0.00000, \mathrm{RMSEA}=0.112$

Şekil 2. İkinci Yapısal Eşitlik Modeline Ait Standart Değerler

\section{Model III'e İlişkin Bulgular}

Araştırmanın üçüncü yapısal eşitlik modelinde literatürden edinilen bilgilere dayanarak birinci ve ikinci modele kıyasla lineer bir model oluşturulmuştur. Oluşturulan üçüncü modelde bilinçli farkındalık, profesyonellik, iş doyumu ve örgütsel bağllık gizil değişkenler; bilinçli farkındalık maddelerinin ortalaması, profesyonelliğin alt boyutları olan mesleki gelişim, öz yeterlilik, iş birliği, kurumsal etkileşim, toplumsal fayda; iş doyumu madde ortalamaları ile örgütsel bağlılığın alt boyutları olan duygusal bağlılık, devam bağlılığı ve normatif bağlılık ise gözlenen değişkenlerdir. Üçüncü modelin test edilmesiyle elde edilen 
uyum indeksleri Tablo 6'da verilmiştir.

Tablo 6. Üçüncü Yapısal Modele İlişkin Uyum İyiliği Parametreleri

\begin{tabular}{ll}
\hline Uyum Parametresi & Kat Say1 \\
\hline GFI & 0.96 \\
AGFI & 0.94 \\
CFI & 0.95 \\
RMSEA & 0.067 \\
$d f$ & 32 \\
$\chi^{2}$ & 150.78 \\
$\chi^{2} / \mathrm{df}$ & 4.71 \\
\hline
\end{tabular}

Üçüncü yapısal modeldeki gizil değişkenler arasındaki nedensel ilişkileri belirleyebilmek amacıyla yapılan yol analizinin sonucuna göre uyum indeksleri $\chi^{2}=150.78 ; \mathrm{df}=32 ; \chi^{2} / \mathrm{df}=4.71$; GFI=0.96; CFI=0.95; AGFI=0.94 ve RMSEA=0.067 olarak bulunmuştur. İkinci modelin uyum iyiliği değerlerine bakıldığında, bu ölçme modelinin iyi bir uyumla kabul edilebilir bir model olduğu ifade edilebilir (Bollen, 1989; Browne ve Cudeck, 1993; Byrne, 2010; Cole, 1987; Hu ve Bentler, 1999; Kline, 2005; Schumacker ve Lomax, 1996; Tanaka ve Huba, 1985). Uyum iyiliği değerlerinin incelenmesinden sonra modeldeki ilişkilerin anlamlı olup olmadığını görebilmek için yapılan t-testi analizi sonuçları Şekil 3'te görülmektedir.

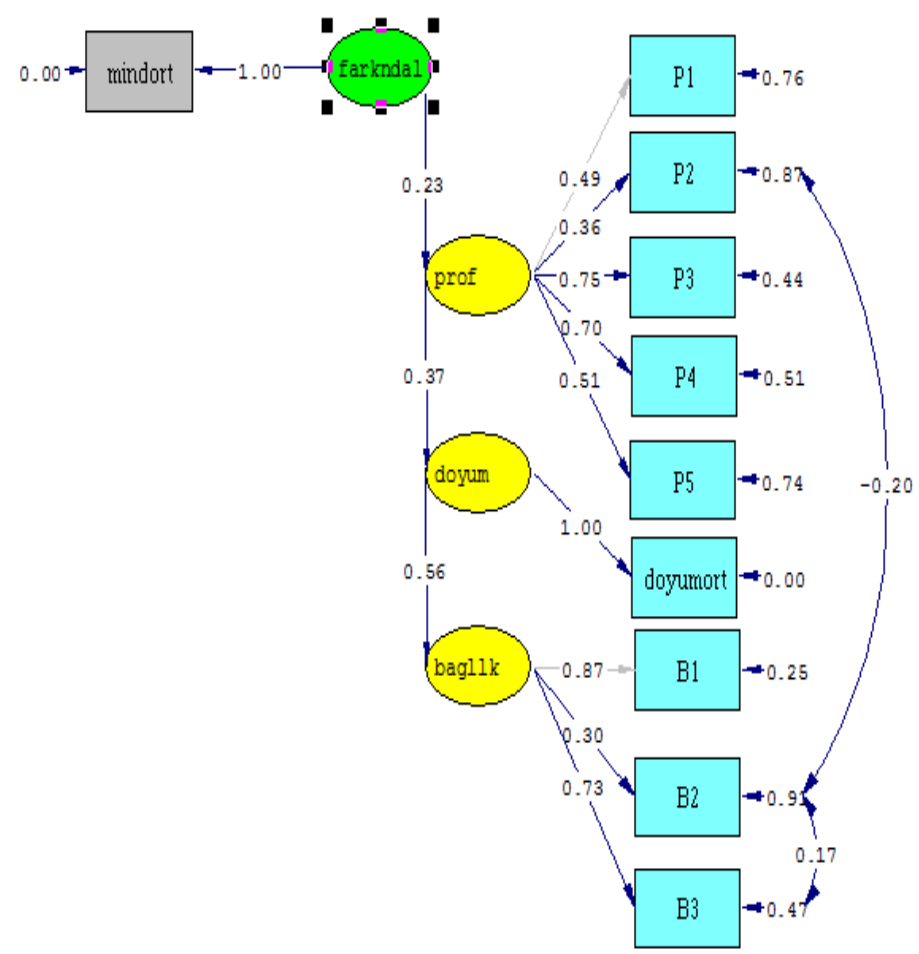

Chi-Square $=150.78, \mathrm{df}=32, \mathrm{P}$-value $=0.00000, \mathrm{RMSEA}=0.067$

Şekil 3. Üçüncü Yapısal Eşitlik Modeli Standart Değerleri 
Uyum iyiliği değerlerinin incelenmesinden sonra modeldeki ilişkilerin ne derece anlamlı olduğunu görebilmek için yapılan t-testi analizi sonuçlarına göre; bilinçli farkındalık ile profesyonellik arasında, profesyonellik ile iş doyumu arasında ve iş doyumu ile örgütsel bağlılık arasında anlamlı ilişkiler vardır. Değişkenler arasında anlamlı ilişkiler tespit edilmesinden sonra değişkenlerin birbirlerine doğrudan ve dolaylı etkileri hesaplanmıştır.

\section{Nihai Modelde Gözlenen Doğrudan Etkiler}

Yol analizindeki katsayılar standardize edilmiş regresyon katsayılarıdır ve bağımsız değişkenin bağımlı değişken üzerindeki doğrudan etkisini göstermektedir. Bağımsız gizil (dışsal) değişkenlerin bağımlı gizil (içsel) değişkenler üzerindeki standardize etkileri Tablo 7'de verilmiştir.

Tablo 7. Üçüncü Yapısal Eşitlik Modeline İlişkin Yol Katsayıları, Anlamlılık ve Belirlilik Katsayıları

\begin{tabular}{|c|c|c|c|c|c|c|}
\hline \multirow{2}{*}{$\begin{array}{l}\text { Dişsal ve İçsel } \\
\text { Değişkenler }\end{array}$} & \multicolumn{2}{|c|}{ Profesyonellik } & \multicolumn{2}{|c|}{ İş Doyumu } & \multicolumn{2}{|c|}{ Örgütsel Bağl1lık } \\
\hline & $\mathrm{t}$ & $\lambda y^{2}$ & $t \lambda y^{2}$ & & $\mathrm{t}$ & $\lambda y^{2}$ \\
\hline Bilinçli Farkındalık & 5.45 & $0.23^{*}$ & - & - & - & - \\
\hline Profesyonellik & - & - & 8.02 & $0.37^{*}$ & - & - \\
\hline İş Doyumu & - & - & - & - & 16.10 & $0.56^{*}$ \\
\hline
\end{tabular}

${ }^{*} \mathrm{p}<0.05$

Tablo 7'de de görüldüğü gibi üçüncü yapısal eşitlik modelinde bilinçli farkındalık ile profesyonellik arasındaki regresyon katsayısına ilişkin $t$-değeri anlamlıdır $(\mathrm{p}<0.05)$ ve öğretim elemanlarının bilinçli farkındalık algılarının profesyonellik algılarını olumlu yönde $\left(\lambda_{\mathrm{y}}{ }^{2}=0.23\right)$ etkilemektedir. Aynı şekilde öğretim elemanlarının profesyonellik algıları iş doyumu algılarını olumlu yönde $\left(\lambda_{y}{ }^{2}=0.37\right)$ etkilemektedir. Modelin son aşamasında görüleceği gibi öğretim elemanlarının iş doyumu algıları örgütsel bağlılık algılarını olumlu yönde $\left(\lambda_{\mathrm{y}}{ }^{2}=0.56\right)$ etkilemektedir.

\section{Nihai Modelde Gözlenen Dolaylı Etkiler}

Ortaya konan yapısal modelde gizil değişkenler arasında doğrudan etkiler görüldüğü gibi, dolaylı etkiler de görülmektedir. Üçüncü modelde öğretim elemanlarının bilinçli farkındalık algılarının profesyonellik algıları üzerinden iş doyumu algılarını olumlu yönde $\left(\lambda_{\mathrm{y}}{ }^{2}=0.09\right)$ etkilediği belirlenmiştir. Bilinçli farkındalığın iş doyumu üzerindeki etki düzeyi; bilinçli farkındalık ve profesyonellik arasındaki yol katsayısı ile profesyonellik ve iş doyumu arasındaki yol katsayısının çarpımı ile hesaplanarak bulunmuştur.

Yapısal modeldeki diğer dolaylı etki incelendiğinde, öğretim elemanlarının bilinçli farkındalık algılarının profesyonellik algıları ve iş doyumu algıları üzerinden örgütsel bağlılık algıları üzerinde olumlu yönde $\left(\lambda_{\mathrm{y}}{ }^{2}=0.05\right)$ etkisi tespit edilmiştir. Bilinçli farkındalığın örgütsel bağlılık 
üzerindeki etki düzeyi; bilinçli farkındalık ile profesyonellik arasındaki yol katsayısı, profesyonellik ile iş doyumu arasındaki yol katsayısı ve iş doyumu ile örgütsel bağlılık arasındaki yol katsayısı çarpımı ile bulunmuştur. Son olarak öğretim elemanlarının profesyonellik algılarının da iş doyumu algıları üzerinden örgütsel bağlılık algıları üzerinde olumlu yönde $\left(\lambda_{\mathrm{y}}{ }^{2}=0.21\right)$ etkisi tespit edilmiştir. Profesyonelliğin örgütsel bağlllık üzerindeki etki düzeyi; profesyonellik ile iş doyumu arasındaki yol katsayısı ve iş doyumu ile örgütsel bağlılık arasındaki yol katsayısı çarpımı ile hesaplanmıştır.

\section{Tartışma}

$\mathrm{Bu}$ araştırma üniversitelerde görev yapan öğretim elemanlarının bilinçli farkındalık, profesyonellik, iş doyumu ve örgütsel bağlılık algıları arasındaki yapısal ilişkileri gösteren teorik modellerin test edilmesi amacıyla yürütülmüştür. Oluşturulan modellerin test edilmesinin öncesinde, öğretim elemanlarının bilinçli farkındalık, profesyonellik, iş doyumu ve örgütsel bağlılık algılarına dair betimleyici istatistikler değerlendirilerek söz konusu değişkenlere ait ortalama değerler ve standart sapmalar dikkate alınmıştır. Araştırma modellerinin sınanmasından önce araştırma modellerinin gizil ve gözlenen değişkenleri arasındaki ilişkiler değerlendirilmiştir.

Bu noktada, profesyonellik algısının bilinçli farkındalık ve iş doyumu ile olumlu yönde orta düzeyde bir ilişkiye sahipken diğer değişkenlerden örgütsel bağlllık ile yine olumlu yönde fakat nispeten düşük düzeyde bir ilişkiye sahip olduğu görülmüştür. Örgütsel bağlılık ile iş doyumu arasında olumlu yönde yüksek düzeyde bir ilişki tespit edilmiştir.

Araştırma kapsamında tasarlanan birinci yapısal modelde öğretim elemanlarının profesyonelliklerinin ve bilinçli farkındalıklarının öğretim elemanlarının iş doyumlarını; iş doyumunun da öğretim elemanlarının örgütsel bağlılıklarını etkilediği ön görülmüş fakat örtük değişkenler arasındaki nedensel ilişkileri gösterebilmek için yapılan yol analizi sonrasında görülen uyum indeksleri modelin kabul edilebilir bir model olmadığını ortaya koymuştur. Ayrıca, modelde tanımlanan ilişkilerden bilinçli farkındalık ve iş doyumu arasındaki ilişkilerin anlamlı olmadığı görülmüştür. Bu sebeple birinci modelden vazgeçilmiştir.

Araştırmanın ikinci yapısal modeli öğretim elemanlarının bilinçli farkındalıklarının profesyonelliği; profesyonelliğin ise iş doyumunu ve örgütsel bağlılı̆̆ı etkilediği düşüncesiyle oluşturulmuştur. Fakat örtük değişkenler arasındaki nedensel ilişkileri gösterebilmek için yapılan yol analizi sonrasında görülen uyum indeksleri, modelin kabul edilebilir bir model olmadığını göstermiştir. Bu sebeple ikinci modelden vazgeçilerek lineer bir model olan üçüncü yapisal model test edilmiştir.

Araştırmanın üçüncü yapısal modelinde, öğretim elemanlarının bilinçli farkındalıklarının profesyonelliği; profesyonelliğin ise iş doyumunu, iş doyumunun da örgütsel bağlllı̆̆ etkilediğini ifade eden lineer bir yapısal model ortaya konmuştur. Modelin örtük değişkenleri arasındaki nedensel ilişkileri gösterebilmek için yol analizinden faydalanılmış ve yüksek uyum iyiliği değerlerine ulaşılmıştır. Elde edilen uyum indeksleri sonrasında oluşturulan modelin mükemmel bir uyumla kabul edilebilir bir model olduğu söylenebilir. Bunun yanı sıra, modeldeki değişkenler arasındaki ilişkilerin anlamlılığı değerlendirildiğinde, bilinçli 
farkındalık ve profesyonellik arasında, profesyonellik ve iş doyumu arasında, iş doyumu ve örgütsel bağlılık arasında anlamlı ilişkiler görülmüştür. Araştırmanın üçüncü modelinin doğrulanması, doğrudan ve dolaylı etkilerin anlamlı oluşu sebebiyle elde edilen araştırma bulguları ilgili alanyazın kapsamında tartışılmıştır.

Oluşturulan modelde bilinçli farkındalık ve profesyonellik arasında orta düzeyde, profesyonellik ve iş doyumu arasında yine orta düzeyde ilişki olduğu bulunmuştur. Modeldeki en güçlü doğrudan etki iş doyumu ve örgütsel bağlllık değişkenleri arasında görülmüştür. Bu noktada bilinçli farkındalık arttıkça profesyonelliğin, profesyonellik arttıkça iş doyumunun, iş doyumu arttıkça örgütsel bağllığın artabileceğini söylemek mümkündür. Elde edilen bu bulgu alanyazındaki araştırma bulgularıyla da tutarlılık göstermektedir (Altınkurt ve Yılmaz, 2014; Huang, 2015; Lovas vd., 2008; Ludmerer, 1999; Roeser vd., 2012; Schappe, 1998; Wang, 2007).

Araştırmanın birinci hipotezi "bilinçli farkındalığın profesyonellik üzerinde etkisi vardır" biçiminde gösterilmiştir. Yapılan analizlerin sonuçları bu hipotezi doğrulamıştır. Alanyazın incelendiğinde, bilinçli farkındalığın kişilerin profesyonellik düzeylerini olumlu yönde etkileyerek profesyonelliğin bir belirleyicisi olduğu görülmektedir (Ludmerer, 1999). Bilinçli farkındalığın profesyonellikle ilişkisini inceleyen Wang, bilinçli farkındalıkları bireylerin benzer şekilde yüksek profesyonellik düzeylerine sahip olduklarını belirtmiştir (Wang, 2007). Yaptığı nitel bir çalışmayla Lovas, profesyonellik ve bilinçli farkındalık kavramlarının birbirinden ayrılamaz iki kavram olduğunu ifade etmektedir. (Lovas vd., 2008). Bireylerin aldıkları bilinçli farkındalık eğitimleriyle profesyonellik düzeyleri, karar verme süreçleri, liderlik süreçleri ve etik algıları olumlu yönde etkilenmektedir (Huang, 2015). Alanyazından elde edilen bu bulgular değerlendirildiğinde, bilinçli farkındalığın profesyonelliği destekleyeceği söylenebilir.

Araştırmanın ikinci hipotezi "bilinçli farkındalığın iş doyumu üzerinde etkisi vardır" biçiminde gösterilmiştir. Yapılan analizlerin sonuçları bilinçli farkındalığın profesyonellik üzerinden iş doyumunu etkilediğini göstererek bu hipotezi doğrulamıştır. Örtük değişkenler arasındaki dolaylı ilişkiler anlamlıdır ve beklenen yöndedir. Ulaşılan bulgulara göre bilinçli farkındalığın iş doyumu üzerindeki dolaylı etkisi anlamlıdır. Profesyonellik değişkeni bilinçli farkındalık ve iş doyumu arasındaki ilişkiye aracılık etmektedir. Böylece, bilinçli farkındalık arttıkça profesyonellik artmakta, profesyonellik arttıkça iş doyumu yükselmektedir. İlgili alanyazın incelendiğinde, bilinçli farkındalığın iş doyumu üzerinde olumlu yönde bir etkisi olduğu görülmektedir (Charoensukmongkol, 2013; Fortney, Luchterhand, Zakletskaia, Zgierska ve Rakel, 2013; Healy ve McKay, 2000; Hoy, 2003; Hulsheger vd., 2013; Kim, 2016). İsmail ve meslektaşları yaptıkları bir çalışmada bilinçli farkındalık ve iş doyumu arasındaki ilişkiye dikkat çekerek bu iki kavramın birlikte işten ayrılma niyetini olumsuz yönde etkilediğini ortaya koymuşlardır (İsmail, Coetzee, Du Toit, Rudolph ve Joubert, 2013). Vaculik ve meslektaşları ise bilinçli farkındalığın iş doyumu üzerinden iş performansını etkilediğ sonucuna ulaşmışlardır (Vaculik, Vytásková, Procházka ve Zalis, 2016). Çalışanlara bilinçli farkındalık eğitimlerinin verilmesiyle çalışanların iş doyumu seviyelerinin yükseldiği, işten kaynaklı stres ve anksiyete seviyelerinde ise düşüş gerçekleştiği gözlemlenmiştir (Wongtongkam, Krivokapic-Skoko, Duncan ve Bellio, 2017).

Araştırmanın üçüncü hipotezi “bilinçli farkındalığın örgütsel bağlılık üzerinde etkisi vardır” 
biçiminde gösterilmiştir. Yapılan analizlerin sonuçları bilinçli farkındalığın profesyonellik ve iş doyumu üzerinden örgütsel bağlılığı etkilediğini göstererek bu hipotezi doğrulamıştır. Araştırma bulguları bilinçli farkındalığın örgütsel bağlılık üstündeki dolaylı etkisini ortaya koymaktadır. Bilinçli farkındalık profesyonellik ve iş doyumu değişkenleri üzerinden örgütsel bağlılığa etki etmektedir. Bu noktada, bilinçli farkındalık arttıkça profesyonellik artmakta, profesyonellik arttıkça iş doyumu yükselmekte, iş doyumu yükseldikçe örgütsel bağl1lık yükselmektedir. Alanyazındaki kısıtlı sayıda görülen diğer çalışmalar da bilinçli farkındalığın örgütsel bağlllık üzerindeki etkisini desteklemektedir (Voci, Veneziani ve Metta, 2016; Vogus ve Sutcliff, 2012). Vogus ve Sutcliffe yaptıkları çalışmayla örgütlerin iyileştirilmesi adına bilinçli farkındalık uygulamalarının önemine dikkat çekerek örgütsel farkındalık kavramını ortaya koymuşlardır (Vogus ve Sutcliff, 2012). Sağlık sektörü çalışanları üzerinde yapılan başka bir çalışmayla bilinçli farkındalığın örgütsel bağlılık üzerindeki olumlu, tükenmişlik üzerindeki olumsuz etkisine dikkat çekilmiştir (Voci vd., 2016). Bu anlamda, bu araştırmanın sonuçlarıyla da uyumlu olarak bilinçli farkındalığın iş doyumunu etkilediği ve dolayısıyla da örgütsel bağlılığa katkıda bulunabileceği düşünülebilir.

Araştırmanın dördüncü hipotezi "profesyonelliğin iş doyumu üzerinde etkisi vardır" biçiminde gösterilmiştir. Yapılan analizlerin sonuçları bu hipotezi doğrulamıştır. Araştırma bulgularına göre profesyonellik iş doyumu üzerinde olumlu bir etkiye sahiptir. İlgili alanyazın profesyonellik düzeyinin yüksekliğinin iş doyumunu artırıcı bir etkiye sahip olduğunu göstermektedir. İş doyumu ve mesleki profesyonellik arasında olumlu yönde bir ilişki vardır (Altınkurt ve Yılmaz, 2014). Profesyonellik düzeyi yüksek okullarda iş doyumu daha yüksektir (Cheng, 1996). Alanyazında profesyonelliğin ve iş doyumu üzerinde etkisine yönelik sınırlı sayıda araştırma yapılmıştır. Yapılan çalışmalar incelendiğinde profesyonellik iş doyumu arasında olumlu yönde ilişkiler görülmüştür (Agho, 1993; Lok, 1999; Lok, 2001; Pollard, 1995). Ortaya konan bulgular, bu araştırmada belirtilen profesyonelliğin iş doyumu üzerindeki etkisini destekler niteliktedir. Bu bağlamda, profesyonellik arttıkça iş doyumunun da artacağı söylenebilir.

Araştırmanın beşinci hipotezi "profesyonelliğin örgütsel bağlllık üzerinde etkisi vardır" biçiminde gösterilmiştir. Yapılan analizlerin sonuçları profesyonelliğin iş doyumu üzerinden örgütsel bağlılığı etkilediğini göstererek bu hipotezi doğrulamıştır. Araştırma sonuçlarına göre profesyonellik iş doyumu üzerinden örgütsel bağlılık üzerinde dolaylı bir etkiye sahiptir. Profesyonellik arttıkça iş doyumu artmakta, iş doyumu arttıkça da örgütsel bağlılık artmaktadır. Başka bir deyişle, öğretim elemanlarının düne ait telaşlarını ve yarına dair endişelerini bir kenara bırakarak günün gerektirdiği sorumluluklarını ertelemeden ve akışa kapılarak gerçekleştirebilmeleri halinde; bu durumun mesleki gelişim süreçlerini, akademik profesyonelliklerini de olumlu yönde etkileyerek iş doyumları ve örgütsel bağlılıkları üzerinde etki göstereceği düşünülebilir. Alanyazında yapılan çalışmalarda bu araştırmanın bulgularına benzer şekilde profesyonelliğin örgütsel bağlllık üzerindeki etkisi görülmektedir (Bartol, 2017; Han, Sohn, Park ve Kang, 2010; Norris ve Niebuhr, 1984; Seijaaka ve Kaawaase, 2014; Shafer, Park ve Liao, 2002). Norris ve Niebuhr (1984) muhasebecileri dahil ettikleri bir çalışmada profesyonelliğin hem iş doyumuna hem de örgütsel bağlılığa yüksek etkisi olduğunu, profesyonellik düzeyi arttıkça iş doyumu ve bağlılık düzeylerinin de arttığını belirtmişlerdir. Shafer ve meslektaşları (2002) muhasebecileri dahil ettikleri bir çalışmada profesyonelliğin örgütsel bağlılık üzerindeki olumlu etkisini göstermişlerdir. Han (2010), 
hemşireleri dahil ettiği çalışmasında profesyonelliğin örgütsel bağlılık üstündeki olumlu, işten ayrılma niyeti üstündeki olumsuz etkisini bulgularında ifade etmiştir. Sejjaaka ve Kaawaase (2014) çalışmalarının sonucunda profesyonelliğin iş doyumu ve örgütsel bağlılığın önemli bir belirleyicisi olduğunu ortaya koymuşlardır. Bartol (2017) çalışmasında profesyonelliğin farklı boyutları üzerine bir inceleme yapmış ve profesyonelliğin örgütsel bağlılık üzerindeki olumlu, işten ayrılma niyet üzerine olumsuz etkilerini göstermiştir.

Araştırmanın altıncı hipotezi "iş doyumunun örgütsel bağlılık üzerinde etkisi vardır" biçiminde gösterilmiştir. Yapılan analizlerin sonuçları bu hipotezi doğrulamıştır. İş doyumu ve örgütsel bağlılık arasında yüksek düzeyde olumlu yönde bir ilişki de tespit edilmiştir. Temel örgütsel çıtılar olarak değerlendirilebilecek iş doyumu ve örgütsel bağlılık kavramları arasındaki ilişki alanyazında yoğun şekilde çalışılmıştır. Alanyazında da iş doyumu ve örgütsel bağlılık arasında olumlu yönde yüksek derecede ilişkiler görülmüştür. Rooser öğretim elemanlarını dahil ettiği bir çalışmasında iş doyumu ve örgütsel bağlılık arasında olumlu yönde yüksek derecede bir ilişki ortaya koymuştur (Roeser vd., 2012). Smadov, işçileri dahil ettiği çalışmasında iş doyumunun örgütsel bağlılık üzerinde olumlu yönde bir etkisi olduğu sonucuna ulaşmıştır (Smadov, 2006). Curry de benzer şekilde iş doyumu ve bağl1lık arasında olumlu yönde orta düzeyde ilişkiler tespit etmiştir (Curry, 1986). Tett ve Meyer alanyazındaki diğer araştırmalar üzerinden yaptıkları bir meta analiz çalışmasında iş doyumu ve bağlılık algılarının birlikte işten ayrılma niyetini yordadıklarını ve iş doyumunun etkisinin bağlılığa göre daha yüksek olduğunu ifade etmişlerdir (Tett ve Meyer 1993). Moorman çalışmasının sonucunda iş doyumu ve örgütsel bağlılık arasında olumlu yönde yüksek derecede ilişki tespit etmiştir (Moorman, Niehoff ve Organ 1993). Güleryüz ve meslektaşları hemşireleri dahil ettikleri çalışmalarının sonucunda iş doyumu ve örgütsel bağlılık arasında olumlu yönde yüksek derecede ilişki bulunduğu sonucuna ortaya koymuşlardır (Güleryüz vd., 2008). Demirel (2009) literatürü destekler şekilde iş doyumu ve örgütsel bağlılık arasındaki önemli ilişkiye dikkat çekmiştir. Alanyazında ulaşılan bulgular bu araştırma sonucunda ulaşılan bulguları desteklemektedir ve öğretim elemanlarının iş doyumları arttıkça örgütsel bağl1lıklarının da artacağı söylenebilir.

$\mathrm{Bu}$ araştırma ile üniversitelerde görev yapan öğretim elemanlarının bilinçli farkındalık, profesyonellik, iş doyumu ve örgütsel bağlılık algıları arasındaki yapısal ilişkileri açıklayan teorik modeller test edilmiş ve öğretim elemanlarının bilinçli farkındalıklarının profesyonelliği; profesyonelliğin ise iş doyumunu, iş doyumunun da örgütsel bağl1lı̆̆ etkilediği sonucuna ulaşılmıştır. Bunun yanı sıra, modeldeki değişkenler arasındaki ilişkilerin anlamlılığı değerlendirildiğinde, bilinçli farkındalık ve profesyonellik arasında, profesyonellik ve iş doyumu arasında, iş doyumu ve örgütsel bağlılık arasında anlamlı ilişkiler görülmüştür.

$\mathrm{Bu}$ araştırma bulgularına dayanarak şu öneriler geliştirilmiştir: Yükseköğretim kurumlarında mesleki gelişim programlarını planlarken bu programların bireylerin yalnızlık duygusunu aşarak kendilerini gerçekleştirme olanağı bulacakları, kişiler arası ilişkilerini geliştirebileceği, mutluluk ve iyimserlik duygularının ön plana çıkartılacağı etkinlikler düzenlenebilir. Öğretim elemanlarına verilen bilinçli farkındalık eğitimlerinin yükseköğretim yöneticilerine, diğer çalışanlara ve öğrencilere de verilmesi yoluyla eğitim kurumunun bütününde bir farkındalık bilinci benimsenebilir. Öğretim elemanlarının mesleki profesyonellikleri, mesleki profesyonelliğin öz yeterlilik, mesleki gelişim, mesleki iletişim, kurumsal ve toplumsal fayda 
boyutlarını güçlendirebilecek hizmet içi eğitim uygulamaları ile desteklenebilir ve sürekliliği sağlanabilir. İleride bu bağlamda farklı eğitim tür ve kademelerinde yapılacak nitel, nicel ve karma araştırmaların eğitim yönetimi alanının bilimsel gelişimine katkı sağlayacağı, özellikle psikolojik öğelerin kurumsal etkililik ve verimlilik üzerinde ne denli önemli olduğunun farkedileceği umulmaktadır.

\section{Araştırmacıların Katkı Oranı}

Makale yazarları makaleye eşit oranda katkı sağlamış olduklarını beyan ederler

\section{Çatışma Beyanı}

Makale yazarları aralarında herhangi bir çıkar çatışması olmadığını beyan ederler.

\section{Kaynakça}

Abenavoli, R. M., Jennings, P. A., Greenberg, M. T., Harris, A. R. ve Katz, D. A. (2013). The protective effects of mindfulness against burnout among educators. Psychology of Education Review, 37(2), 57-69.

Agho, A. O., Mueller, C. W. ve Price, J. L. (1993). Determinants of employee job satisfaction: An empirical test of a causal model. Human Relations, 46(8), 1007-1027.

Altınkurt, Y. ve Yılmaz, K. (2014). Öğretmenlerin mesleki profesyonelliği ile iş doyumları arasındaki ilişki. Sakarya University Journal of Education, 4(2), 57-71.

Aydın, A. (2015). Ĕğitim politikası. Ankara: Pegem Akademi.

Baer, R. A., Smith G. T. ve Allen, K. B. (2004). Assessment of mindfulness by self-report the Kentucky inventory of mindfulness skills. Assessment, 11(3), 191-206.

Bartol, K. M. (2017). Professionalism as a predictor of organizational commitment, role stress, and turnover: A multidimensional approach. Academy of Management Journal, 22(4), 815821.

Başkan, G. A. (2001). Türkiye'de yükseköğretimin gelişimi. Gazi Üniversitesi Gazi Ĕ̆gitim Fakültesi Dergisi, 21(1), 21-32.

Becker, H. S. (1960). Notes on the concept of commitment. American Journal of Sociology, 66(1), 32-40.

Bollen, K. A. (1989). A new incremental fit index for general structural equation models. Sociological Methods and Research, 17(3), 303-316.

Browne, M. W. ve Cudeck, R. (1993). Alternative ways of assessing model fit. Sage Focus Editions, 154, 136-136.

Byrne, B. M. (2010). Structural equation modeling with AMOS: Basic concepts, applications, and programming (2nd ed.). New York: Taylor and Francis.

Büyüköztürk, Ş., Çakmak, E. K., Akgün, Ö. E., Karadeniz, Ş. ve Demirel, F. (2017). Bilimsel araştırma yöntemleri. Ankara: Pegem. 
Charoensukmongkol, P. (2013). The contributions of mindfulness meditation on burnout, coping strategy, and job satisfaction: Evidence from Thailand. Journal of Management EOrganization, 19(5), 544-558.

Cheng Y. C. (1996). Relation between teachers' professionalism and job attitudes, educational outcomes, and organizational factors. The Journal of Educational Research, 89(3), 163-171, DOI: $10.1080 / 00220671.1996 .9941322$

Cole, D. A. (1987). Utility of confirmatory factor analysis in test validation research. Journal of Consulting and Clinical Psychology, 55, 1019-1031.

Curry, J. P., Wakefield, D. S., Price, J. L. ve Mueller, C. W. (1986). On the causal ordering of job satisfaction and organizational commitment. Academy of Management Journal, 29(4), 847858.

Davis, K. (1982). İşletmelerde insan davranışı. İstanbul: İstanbul Üniversitesi Yayını.

Demirel, Y. (2009). Örgütsel bağl1lık ve üretkenlik karşıtı davranışlar arasındaki ilişkiye kavramsal yaklaşım. İstanbul Ticaret Üniversitesi Sosyal Bilimler Dergisi, 8(15), 115-132.

Field, A. (2009). Discovering statistics using SPSS (3rd ed.). London: Sage.

Firestone, W. A. ve Pennell, J. R. (1993). Teacher commitment, working conditions and differential incentive policies. Review of Educational Research, 63(4), 489-525.

Flook, L., Goldberg, S. B., Pinger, L., Bonus, K. ve Davidson, R. J. (2013). Mindfulness for teachers: A pilot study to assess effects on stress, burnout, and teaching efficacy. Mind, Brain, and Education, 7(3), 182-195.

Fortney, L., Luchterhand, C., Zakletskaia, L., Zgierska, A. ve Rakel, D. (2013). Abbreviated mindfulness intervention for job satisfaction, quality of life, and compassion in primary care clinicians: A pilot study. The Annals of Family Medicine, 11(5), 412-420.

Fraenkel, J. R. ve Wallen. N. E. (2006). How to design and evaluate research in education. New York: Mc Grawal Hill.

Gold, E., Smith, A., Hopper, I., Herne, D., Tansey, G. ve Hulland, C. (2010). Mindfulness-based stress reduction (MBSR) for primary school teachers. Journal of Child and Family studies, 19(2), 184-189.

Güleryüz, G., Güney, S., Aydin, E. M. ve As, Ö. (2008). The mediating effect of job satisfaction between emotional intelligence and organizational commitment of nurses: A questionnaire survey. International Journal of Nursing Studies, 45(11), 1625-1635.

Hall, R. H. (1967, Ağustos). Components of professionalization. Amerika Sosyoloji Birliği Yıllık Toplantısı'nda sunuldu, San Francisco, California.

Hall, D. T., Schneider, B. ve Nygren, H. T. (1970). Personal factors in organizational identification. Administrative Science Quarterly, 176-190.

Hamburg, M. (1995). Basic statistics: A modern approach. New York: Harcourt, Brace Jovanovich.

Han, Y. H., Sohn, I. S., Park, K. O. ve Kang, K. H. (2010). The relationships between professionalism, job involvement, organizational commitment and turnover intention among clinical nurses. Journal of Korean Clinical Nursing Research, 16(2), 17-31. 
Havas, A. (2008). Devising futures for universities in a multi-level structure: A methodological experiment. Technological Forecasting \& Social Change, 75, 558-582.

Healy, C. M. ve McKay, M. F. (2000). Nursing stress: The effects of coping strategies and job satisfaction in a sample of Australian nurses. Journal of Advanced Nursing, 31(3), 681-688.

Huang, P. H. (2015). How improving decision-making and mindfulness can improve legal ethics and professionalism, Journal of Law, Business and Ethics, 21, 35-76.

$\mathrm{Hu}, \mathrm{L}$. T. ve Bentler, P. M. (1999). Cutoff criteria for fit indexes in covariance structure analysis: Conventional criteria versus new alternatives. Structural Equation Modeling: A Multidisciplinary Journal, 6(1), 1-55.

Hulsheger, U. R., Alberts, H. J., Feinholdt, A. ve Lang, J. W. (2013). Benefits of mindfulness at work: the role of mindfulness in emotion regulation, emotional exhaustion, and job satisfaction. Journal of Applied Psychology, 98(2), 310.

Ismail, H. A. K., Coetzee, N., Du Toit, P., Rudolph, E. C. ve Joubert, Y. T. (2013). Towards gaining a competitive advantage: The relationship between burnout, job satisfaction, social support and mindfulness. Journal of Contemporary Management, 10(1), 448-464.

Karasar, N. (2005). Bilimsel araştırma yöntemi kavramlar ilkeler teknikler. Ankara: Nobel.

Kline, R. B. (2005). Principle and practice of structural equation modeling. New York: Guilford.

Locke, E. A. (1970). Job satisfaction and job performance: A theoretical analysis. Organizational Behavior and Human Performance, 5(5), 484-500.

Lok, P. ve Crawford, J. (1999). The relationship between commitment and organizational culture, subculture, leadership style and job satisfaction in organizational change and development. Leadership and Organization Development Journal, 20(7), 365-374.

Lok, P. ve Crawford, J. (2001). Antecedents of organizational commitment and the mediating role of job satisfaction. Journal of Managerial Psychology, 16(8), 594-613.

Lovas, J. G., Lovas, D. A. ve Lovas, P. M. (2008). Mindfulness and professionalism in dentistry. Journal of Dental Education, 72(9), 998-1009;

Ludmerer, K. M. (1999). Instilling professionalism in medical education. Jama, 282(9), 881-882. doi:10.1001/jama.282.9.881

Marginson, S. (2000). Rethinking academic work in the global era. Journal of Higher Education Policy and Management, 22(1), 23-35.

McCormick, E. J. ve Ilgen, D. (1980). Industrial psychology. New Jersey: Prentice Hall.

Moorman, R. H., Niehoff, B. P. ve Organ, D. W. (1993). Treating employees fairly and organizational citizenship behavior: Sorting the effects of job satisfaction, organizational commitment, and procedural justice. Employee Responsibilities and Rights Journal, 6(3), 209-225.

Neuman, W. L. ve Robson, K. (2007). Basics of social research: Qualitative and quantitative approaches. Power, $48,48$.

Nguni, S., Sleegers, P. ve Denessen, E. (2006). Transformational and transactional leadership effects on teachers' job satisfaction, organizational commitment, and organizational 
citizenship behavior in primary schools: The Tanzanian case. School Effectiveness and School Improvement, 17(2), 145-177.

Nixon, J., Marks, A., Rowland, S. ve Walker, M. (2010). Towards a new academic professionalism: a manifesto of hope. British Journal of Sociology of Education, 22(2), 227244.

Norris, D. R. ve Niebuhr, R. E. (1984). Professionalism, organizational commitment and job satisfaction in an accounting organization. Accounting, Organizations and Society, 9(1), 4959.

Pearson, L. C. ve Moomaw, W. (2005). The relationship between teacher autonomy and stress, work satisfaction, empowerment, and professionalism. Educational Research Quarterly, 29(1), 38-54.

Pollard, G. (1995). Job satisfaction among newsworkers: The influence of professionalism, perceptions of organizational structure, and social attributes. Journalism and Mass Communication Quarterly, 72(3), 682-697.

Rasmussena, E., Moenb, O. ve Gulbrandsenc, M. (2006). Initiatives to promote commercialization of university knowledge. Technovation, 26, 518-533.

Roeser, R. W., Skinner, E., Beers, J. ve Jennings, P. A. (2012). Mindfulness training and teachers' professional development: An emerging area of research and practice. Child Development Perspectives, 6(2), 167-173.

Scarbrough, C. S. (2005). Aspects of school mindfulness and dimensions of faculty trust: Social processes in elementary school. Yayımlanmamış doktora tezi. The University of Texas, San Antonio.

Schappe, S. P. (1998). The influence of job satisfaction, organizational commitment, and fairness perceptions on organizational citizenship behavior. The Journal of Psychology, 132(3), 277-290.

Schumacker, R. E. ve Lomax, R. G. (1996). A beginner's guide to structural equation modeling. New Jersey: Erlbaum.

Sejjaaka, S. K. ve Kaawaase, T. K. (2014). Professionalism, rewards, job satisfaction and organizational commitment amongst accounting professionals in Uganda. Journal of Accounting in Emerging Economies, 4(2), 134-157.

Shafer, W. E., Park, L. J. ve Liao, W. M. (2002). Professionalism, organizational-professional conflict and work outcomes: A study of certified management accountants. Accounting, Auditing $\mathcal{E}$ Accountability Journal, 15(1), 46-68.

Smadov, S. (2006). İş doyumu ve örgütsel bağhllık: Özel sektörde bir uygulama. Yayımlanmamış doktora tezi. Dokuz Eylül Üniversitesi, Sosyal Bilimler Enstitüsü, İzmir.

Svensson, L. G. (2003). The quest for professionalism and the dialectic of individualism and collectivism in work organisations. Knowledge, Work \& Society, 1(1), 107-129.

Tabachnick, B. ve Fidell, L. (2013). Using multivariate statistics, 6th International Edition. Boston: Mass.

Tanaka, J. S. ve Huba, G. J. (1985). A fit index for covariance structure models under arbitrary GLS estimation. British Journal of Mathematical and Statistical Psychology, 38(2), 197-201. 
Tett, R. P. ve Meyer, J. P. (1993). Job satisfaction, organizational commitment, turnover intention, and turnover: path analyses based on meta-analytic findings. Personnel Psychology, 46(2), 259-293.

Vaculik, M., Vytásková, J., Procházka, J. ve Zalis, L. (2016). Mindfulness, job satisfaction and job performance: Mutual relationships and moderation effect. International Scientific Conference Economics and Management, 21, 148-156.

Voci, A., Veneziani, C. A. ve Metta, M. (2016). Affective organizational commitment and dispositional mindfulness as correlates of burnout in health care professionals. Journal of Workplace Behavioral Health, 31(2), 63-70.

Vogus, T. J. ve Sutcliffe, K. M. (2012). Organizational mindfulness and mindful organizing: A reconciliation and path forward. Academy of Management Learning \& Education, 11(4), 722735.

Wang, S. J. (2007). Mindfulness meditation: Its personal and professional impact on psychotherapists. The Sciences and Engineering, 67(7), 4122.

Wongtongkam, N., Krivokapic-Skoko, B., Duncan, R. ve Bellio, M. (2017). The influence of a mindfulness-based intervention on job satisfaction and work-related stress and anxiety. International Journal of Mental Health Promotion, 19(3), 134-143. 